ARTICLE

DOI: $10.1057 /$ s41599-017-0032-1

\title{
From the exclusion of the people in neoliberalism to publicity without a public
}

\author{
Regina Queiroz ${ }^{1}$
}

\begin{abstract}
This paper argues that the neoliberal political order relies on a particular concept of publicity - the concept of openness or transparency without a public (a populus or demos), the main content of which is the unconditional maxim "There Is No Alternative" (TINA for short). Its central claim is that the neoliberal conception of publicity without a public, connected as it is to secrecy and unconditional adherence to TINA, precludes the possibility of the "people" as an ultimate intentional sovereign legislator. Although research has revealed the strategic importance of publicity for communicative capitalism, this aspect of neoliberalism has yet to be addressed. As a means of clarifying the neoliberal concept of publicity, this paper will show that neoliberal theory cannot consistently accept the existence of the people as sovereign while maintaining its adherence to TINA. Second, it invokes the Kantian conception of publicity, which involves not merely openness and visibility but also the will of the populus. One of Kant's central insights is that publicity is a necessary (but not sufficient) condition for fairness at the level of political decision-making. When public (openly accessible) statements are not based on the will of the people, publicity can become a means of illegitimate political domination against sovereign peoples. Building on Kant's insights, this paper will show that publicity without a public, along with its central mantra, TINA, is also, at the practical level, neoliberalism's main means of destroying the legislative sovereignty of the people. Since TINA precludes the possibility of the people as sovereign, analysis of the neoliberal conception of publicity that underlies TINA provides new arguments for the view that neoliberalism is essentially despotic in nature. It also points to the importance of the political category of "the sovereign people", which is all the greater where illiberal and undemocratic political alternatives jockey to fill the vacuum left by a system that, at its ideological core, cannot acknowledge the common good.
\end{abstract}

\footnotetext{
${ }^{1}$ Nova Institute of Philosophy (IFILNOVA), New University of Lisbon, Lisbon, Portugal. Correspondence and requests for materials should be addressed to R.Q. (email: queiroz.regina@gmail.com)
} 


\section{Introduction}

he supposed inevitability of proposed or adopted political measures is commonly appealed to in various political systems. It plays a special role in neoliberalism, however, accompanying almost all policy announcements (including announcements of fiscal consolidation, cuts to social security, the privatization of public property, the liberalization of collective bargaining, and the shrinking of pensions (see Barro, 2009; Cochrane, 2009)). Indeed, the public profession to there being no alternative was ubiquitous in Great Britain under Margaret Thatcher (Jenkins 200) and in Portugal under Passos Coelho (MN Deutsche Börse Group, 2012), and it continues to function in Germany under Merkel (Europe, 2015) and in Greece under Tsipras (Reuters, 2015) (see also the imposition of neoliberal policies in Chile under Pinochet (Munck, 2003), in Argentina under Menem (Vellinga, 1997), in Brazil under Color de Mello (Novelli, 2002), and in Peru under Fujimori (Ugarteche, 1998)).

Against the backdrop of this systematic pattern, this paper argues that TINA is not simply a phrase coined by Margaret Thatcher (Jenkins, 2007) without conceptual value. Besides being the main feature of neoliberal theory (Queiroz, 2016), it has a pivotal political function in the neoliberal project of political domination, as part of a specific and peculiar concept of publicity: openness or visibility without a public (a populous or demos). The main content of the concept of publicity without a public is neoliberalism's unconditional adherence to TINA itself, which, when combined with secrecy, precludes the possibility of individual liberty under a system of collective deliberation, i.e., a system of ultimate intentional lawmakers: the peoples' sovereign (Locke, 1679 [1960]) or the universal sovereign (Kant, 1797 [1977]). Therefore, TINA becomes a key means of despotic political domination.

Research has already revealed the strategic importance of publicity to neoliberalism and to communicative capitalism in particular (Barney, 2008; Dean, 2003, 2008). As a central part of neoliberalism (Barney, 2008), communicative capitalism relies on the transfer of information and communication commodities via a variety of networked technologies (Dean, 2003, 2008); the relevant communication, however, takes place between private individuals and economic and financial institutions. The ostensible transparency of this communication makes communicative capitalism seem perfectly natural and creates the appearance of publicity. This appearance of publicity is pivotal to neoliberalism; it relies fundamentally on secrecy, however, and works to ensure the continued political dominance of the neoliberal order. Although approaches such as Dean's and Barney's stress important features of the relationship between neoliberalism and publicity, the concept of publicity as openness or visibility without a public (a populus or demos), the main content of which is TINA itself, has yet to be addressed in the literature.

To better understand the neoliberal concept of publicity and the relationship between TINA, publicity, and secrecy as a means of political domination, this paper will compare Kantian and neoliberal philosophical conceptions of publicity (Kant, 1793 [1997]). Insofar as it requires not only openness and visibility but also the existence of a populus (Kant, 1795/96 [1997]), the Kantian conception of publicity establishes a theoretical link between secrecy, publicity and the people-a connection that has been drawn on in contemporary political philosophy (Fraser, 1999; Bohman, 1999; Habermas, 1989). The Kantian conception also shows that publicity is merely necessary for fairness, not sufficient. Fair public maxims or policies must also comply with the will or law of the people. Publicity, on this view, must be grounded in a public.

It cannot be denied i) that theoretical problems underlie the Kantian conception of publicity (e.g., the extreme degree of secrecy and suppression entailed by this view (Davis, 1991) and the irreducible element of secrecy that remains in all forms of publicity (Bennington, 2011)); ii) that there are questions concerning both the relationship between self-frustration and injustice in Kant's account and the scope of public maxims (Gosseries, 2005); and iii) that there are questions about how to distinguish between just and unjust maxims and apply this procedure to concrete cases (Gosseries, 2005). There are also clear difficulties involved in moving from hypothetical tests to real-life events, and from political maxims to action itself (e.g., the obscurity of Kant's examples (Elster, 1998)). Finally, it must also be acknowledged that the philosophical scope of the Kantian conception of publicity means that it cannot adequately speak to neoliberal strategies for accumulating class power or to the role of key social forces in neoliberalism's development into a new mode of regulation and action (Hall, 2011; Klein, 2007; Overbeek, 1993; Overbeek and Pijl, 1993; Teubal, 2004).

Despite these limitations, however, Kant's reflections on political publicity, especially the public basis of the visibility of political statements, have much to contribute to our understanding of the despotic nature of neoliberalism (Brown, 2015; Bruff, 2014). On the one hand, "actual publicity can be looked at through the prism of hypothetical publicity" (Gosseries 2005, p 10); on the other, despite Kant's abstract approach to politics in general and to political publicity in particular, a pragmatic and actual (as opposed to hypothetical) perspective on politics and publicity is highly useful (an example of this is his analysis of the right to rebellion under the only rational and transcendental principle of publicity (Kersting, 1992; Riley, 1973)). Moreover, the fact that the Kantian political perspective on publicity evolved in a liberal context in which individual political liberty and the existence of the people (as sovereign) were not dissociated leads to convincing arguments, from a liberal perspective, against both neoliberal theoretical and ideological premises and the deleterious political effects of neoliberal policies (e.g., populism and the erosion of democratic institutions (Brown, 2015; Bruff, 2014; KreuderSonnen and Zangl, 2015; Orphanides, 2014; Schmidt and Thatcher, 2014)).

Section 1 argues that neoliberalism cannot consistently accept the existence of the people while maintaining its adherence to TINA and to the denial of the people as sovereign that it entails. It is argued that the denial of the existence of the sovereign people as a collective, intentional body lies at the core of neoliberalism. Despite the "liberal" in neoliberalism, the denial of the people as sovereign departs from the classical (Locke, 1679 [1960]; Kant, 1793 [1977], 1795/6) liberal tradition. The second section compares Kantian and neoliberal approaches to political publicity, stressing the intrinsic relationship between neoliberalism's publicity without a public, TINA, and secrecy. Here it is emphasized that the neoliberal approach to publicity departs from the liberal tradition of political publicity, as the Kantian conception illustrates (Kant, 1795/96 [1977]).

\section{The denial of the people as sovereign}

It would be a mistake to think that there is a single, "pure" form of neoliberalism. Instead, there are varied articulations of neoliberal ideas at multiple sites (Latin America, Europe, China (Harvey, 2005)) and on multiple scales (national, international, transnational, global (Brown, 2006; Hall, 2011; Klein, 2007; Overbeek, 1993; Overbeek and Pijl, 1993)). As an ideology-as a set of adjustable, evolving matrices of ideas and values that are articulated but also adapted by ideologues and proponents in various ways depending on the circumstances-neoliberalism centers on the ideas of the individual, freedom of choice, market security, 
laissez-faire regulation, and minimal government (Larner, 2006; Mudge, 2008).

Neoliberalism is also characterized by "massive expansion of the field and scope of economics" (Read, 2009, p 28), to the point that it has become a form of economism, approaching social facts as inherently reducible to economic dimensions (Hall, 2011). Under economism, neoliberals transpose the economic market model onto society as a whole (Buchanan and Tullock, 1962, 1987; Hayek, 1976; Nozick, 1974). This translation is based on various concrete activities and processes (see for example Hall, 2011; Harvey, 2005; Klein, 2007; Overbeek, 1993; Overbeek and Pijl, 1993; and Teubal). At the level of political theory, economism is also deeply characteristic of Nozick's political philosophy and his identification of the invisible hand as the leading social principle (Nozick, 1974). It is also clearly at work in Buchanan and Hayek; both view individual political motivation in terms of the homo economicus model (Buchanan and Tullock, 1962; Brennan and Buchanan, 1985; Buchanan, 2000), a conception that is also central to Hayek's understanding of societies and markets as spontaneous orders (Hayek 1976).

Nonetheless, neoliberalism is more than an economic fact (Brown, 2006, 2015; Dean, 2015; Foucault, 2008; Harvey, 2005; Ramey, 2015). Rooted in political philosophy (Nozick 1974), economics, and political economy (Brennan and Buchanan, 1985; Friedman, 1953; Hayek, 1976), neoliberalism is a conception of the world, or a "total view of reality" (Ramey, 2015, p 3). Its central tenets have been integrated into common sense, transforming ideology (Read, 2009). Applicable not only to the political realm but also to the entirety of human existence, the neoliberal ideology was not generated by the state. It resulted from the everyday experience of buying and selling commodities in the market, a model which was then transformed into the image of society. As a total view of reality, neoliberalism entails "a new understanding of human nature and social existence (and) the way in which human beings make themselves and are made subjects" (Read, 2009, p 28; see also Foucault, 2008).

Although Read's, (2009) and Ramey's, (2015) characterizations of neoliberalism are astute, it is important to acknowledge that, as a conception of the world and a total view of reality, neoliberalism is inherently and intrinsically incompatible with the existence of the people as sovereign. Even if neoliberal thinkers do not explicitly argue against the idea of the people in anything like the way that they argue against society and the state (Buchanan and Tullock, 1962; Brennan and Buchanan, 1985; Hayek, 1976; Nozick, 1974), they reject the notion of a "mystical general will" (Buchanan and Tullock, 1962, p12), which is commonly related to peoples' sovereignty (Kant, 1793 [1977], 1795/96 [1977]; Rousseau, 1762 [1964]). Moreover, whereas they explicitly profess that "there is no alternative" (TINA) and that "there is no society" (TINS) (Jenkins, 2007), neoliberal politicians do not likewise explicitly profess that there is no such thing as the sovereign people. Despite this silence, the following aims to show that neoliberal theory and practice indeed reject the concept of peoples in general, and the sovereign people in particular.

The significance of the people as a locus of collective agency. Theorists tend to disagree about whether "the people" ought to be defined on political (Dahl, 1998) or ethnic (Habermas, 2000) lines, and there is little consensus on the appropriate criteria in general (Dahl, 1998; Rawls, 1999; Sieyes, 1789 [1989]). Nonetheless, a rough conception of the people has been available at least since the time of Cicero, who envisioned it as "an assemblage of some size associated with one another through agreement on law and community of interest" (Cicero, 1999, I, p 39, emphasis added; see also Hobbes, 1651 [1996], Locke, 1679 [1960], Kant, 1793 [1977], and Rousseau, 1762 [1964]). Putting to the side the theoretical ambiguity underlying the concept (Agamben, 1996), for the purposes of this paper "the people" shall refer to the citizens of a given political community, i.e., to a unitary political body (demos or populus), understood as the ultimate intentional lawmaker, or the sovereign (Hobbes, 1651 [1996]; Locke, 1679 [1960]). As such, it refers neither to an assemblage of persons defined by their own history, culture, or traditions (ethnos) nor to a particular class of citizens, for example the poor, the disinherited or the wretched in a particular political community (e.g., the plebs (Agamben, 1996; Breaugh, 2007; Sieyes, 1789 [1989])). Despite the relevance of these axes and the interesting relationships between them (Agamben, 1996; Breaugh, 2007), the concept of "the people" (the populus) is an intrinsically political notion. The introduction of law in a given territory allows for the reconciliation of unavoidable ethnic and individual differences (e.g., class differences).

Neoliberal theory can accommodate the idea of individual persons agreeing on laws that apply to all-even in the absence of a common interest (e.g., Hayek, 1976; Brennan and Buchanan, 1985; Buchanan 1990, 2000). Nevertheless, from the contractualist perspective, neoliberal agreement depends on a collective choice "based on a calculus of individual interests" (Buchanan, 1990, p 7), which excludes common presuppositions about the ultimate source of value and the valuation of individual interests. When political decisions are based on common presuppositions about the ultimate source of value and valuation, decision-makers act as collective agents (e.g., peoples) rather than individuals. A central tenet of neoliberalism is that collective deliberation of this sort limits, and even undermines, individuals' ability to maximize their self-interest. Indeed, on the market model, and within the limits of market rules, individuals maximize their net wealth in accordance with exclusively private values. Consequently, coordination based on common values is viewed as preventing people from freely exercising their power. Rather than liberty, deliberation from the standpoint of "the people" is thought to lead to oppression. The "collective" in collective choice merely signifies individualistic political agreement on common political principles. These principles are both chosen from the standpoint of private interest and acted on in the sphere of private calculation. As Dean clearly explains, the economic market cannot be viewed as "the mechanism by which the will of the demos manifests itself" (2008, p 104).

It is true that Buchanan distinguishes the economic domain from the political (Brennan and Buchanan, 1985). The economic refers only to the model of straightforward individual wealth maximization, and politics relates to "all members of a politically organized community [who] are potentially affected by the outcome of a decision that must be made between two courses of action" (Brennan and Buchanan, 1985, p 41). Nevertheless, the distinction between the economic and the political realm does not really challenge the idea of collective choice (or deliberation) on the economic model. If "an individual in a market setting is to be presumed to exercise any power he possesses [...] so as to maximize his net wealth, then an individual in a corresponding political setting must also be presumed to exercise any power he possesses (within the limits of political rules) in precisely the same way" (Brennan and Buchanan, 1985, p 43; see also 1962). The fact that individual free choice is made under political rules does not mean that it results from common deliberation of any sort. In reality, under the homo economicus model self-interested individuals are not concerned with political policies that affect all members of a politically organized community. As purely rational egoists, they pursue selfish personal interest unrestrictedly (Dean, 2015; See also Foucault, 2008; Brown, 2015).

Since political rules are viewed as being analogous to economic market rules, Buchanan therefore consistently concludes that " $\mathrm{t}]$ 
he contractarian contends that politics is best modeled as being analogous to the economic relationship" (Brennan and Buchanan, $1985 \mathrm{p}$ 43), such that "[h]omo economicus is a uniquely appropriate caricature of human behavior" (Brennan and Buchanan, 1985, p 61). Given this "uniquely appropriate caricature of human behavior", and since the individual qua homo economicus is viewed as only looking after his or her own well-being, the idea of all members of a politically organized community deciding from the perspective of all, i.e., as a unitary political body, is rendered both incoherent and undesirable. Like all forms of collective agency, "the people" understood as a sovereign body, as a politically organized community that decides from the perspective of all, is viewed from the neoliberal standpoint as a meaningless or mystical political category (Brennan and Buchanan, 1985).

The spontaneous order as the ultimate legislative power. Besides reducing politics to economics and almost erasing the autonomy of the political realm entirely (Brown, 2006; Foucault, 2008), what is really at stake in Buchanan's approach is that the collective choice that underlies the social contract or political government does not allow for the transformation of individual personalities or isolated natural selves into a collective or single public, viewed as the ultimate intentional lawmaker. To the extent that the role of ultimate intentional lawmaker is taken from the people and given to the invisible hand-or, as in Hayek's political and economic theory, to the analogous idea of the spontaneous order - the people is stripped of its sovereignty. The spontaneous order renders precise the abstract rules (applied to "an unknown number of future instances" (Hayek, 1976, p 35)) that are based on individuals' instrumental agreement on means, not ends, and it is thereby transformed into the sovereign lawmaker. As a sovereign, its commands are immediately and unconditionally based on individuals' free choices- they arise without intentional public mediation and are not conditional on any other factors.

For that reason, when deliberating on the outcomes of a decision that potentially affect all members of a politically organized community, "there is no alternative" to the neoliberal decisions made by that order. Under TINA, individuals ought to "pursue their goals in such a way that they follow the inevitable law(s) of the spontaneous order". As a mirror of immediate, unconditional self-interest (Queiroz, 2016), TINA precludes the possibility of individual liberty under a system of collective deliberation, i.e., a system of ultimate intentional lawmakers (the peoples' sovereign (Locke, 1679 [1960]) or the universal sovereign (Kant, 1797 [1977])). For example, neoliberal policies (e.g., fiscal consolidation, cuts to social security, the privatization of public property, the liberalization of collective bargaining, and the shrinking of pensions (Barro 2009; Cochrane 2009)) have caused harmful effects, including poverty and inequality (Ball et al., 2013; Edmiston, 2014; Greer 2014; Stiglitz, 2013), higher rates of suicide (Antonakakis and Collins 2014), state bankruptcy (Teubal, 2004), and state authoritarianism (Brown, 2006, 2015; Bruff, 2014; Kreuder-Sonnen and Zangl, 2015; Orphanides, 2014; Schmidt and Thatcher, 2014). If individuals are tempted to appeal to intentional political policies when facing these effects, TINA commands that, instead of looking for public solutions issuing from intentional public deliberation, they should only obey the rules of the spontaneous order. Just as poverty and inequality do not depend on intentional individual and public choices, overcoming them does not depend on intentional public decisions (Hayek, 1976; Nozick, 1974). Poverty and inequality only result from the inevitability of apparently inhuman, spontaneous mandates (see also the powerful social and political forces corresponding to this spontaneity, e.g., multinational corporations, as discussed in Hall, 2011; Harvey, 2005; Klein, 2007; Overbeek, 1993; Overbeek and Pijl, 1993; and Teubal, 2004).

This does not mean that neoliberal theory completely rejects the idea that groups of individuals can unite and act unselfishly (Nozick, 1974, p 325) or that such a union can achieve a "common highest good" in some sense (Nozick, 1974, p 325). Nevertheless, since they view the notion of a common good pursued (or willed) by all as corresponding to a socialist conception of the total community, theorists like Nozick reject the idea that "there is a common good that all pursue jointly" (Nozick, 1974, p 325). Despite widespread controversy concerning the meaning and content of "socialism" - a concept that includes distinct traditions and various essential values (e.g., liberty, equality, fraternity, social justice (Barker, 1987; Crick, 1987))—Nozick's understanding of the centrality to socialism of concepts such as unity, the collective common good, and total communities (Nozick, 1974, p 325) leads him to infer that all joint pursuits (by the people) of a common good are species of socialism (including the pursuit described by Rawls in A Theory of Justice). From this perspective, to the extent that they presuppose an "all", or a people who jointly pursue a common good in a total (if not totalitarian) community, Locke's, (1679 [1960]), Kant's, (1793 [1977]), and Rawls's, (1971, 1993) political theories turn out to be socialist in nature. The political, then, is incompatible with a populus or demos as the ultimate sovereign.

It can be argued that under neoliberalism there is no longer a sovereign (Foucault, 2008). On the assumption that sovereignty involves reconciling disparate points of view, the fact that the economic market is characterized by the pursuit of individual well-being, along with the fact that this descent into self-interest is a necessary condition of attaining personal and common wellbeing, undermines both knowledge of common interests and their pursuit. Any collective convergence of interests results from a spontaneous process. Consequently, the invisible hand metaphor undermines the conceivability of the notion of a political sovereign (Foucault, 2008) in general, and peoples' sovereignty in particular. Instead of the sovereign people, neoliberals exalt the sovereign selfish individual (Foucault, 2008).

Nonetheless, even if the invisible hand renders the political sovereign inconceivable, it alone is not responsible for the rejection of the people as sovereign. Foucault, (2008) argues that liberalism still conceives of the difference between the natural space of spontaneity (the space of the economic market) and the political and deliberative scope of politics, whereas neoliberalism reduces the naturalistic perspective of the state to the perspective of the market. Instead of limiting or intervening in a natural and spontaneous market, mainly understood as a space of exchange, political institutions (e.g., the state) ought to create the political conditions to preserve that market, as a place of competition (Foucault, 2008; Read, 2009). Accordingly, neoliberalism's main aim consists in creating the formal political conditions for fostering pure market competition.

From this perspective, neoliberalism is a form of government, or governmentality, which ought to create, or impose on the whole of society, the institutional conditions to ensure the unrestricted maximization of private well-being (Foucault, 2008; Read, 2009). This political creation leaves no room for alternative projects, i.e., projects that challenge economic market mechanisms. In truth, neoliberal governmentality transforms natural into political necessity, i.e., transforms the natural market laissez faire into a political imperative, in such a way that the realm of political deliberation is thus constrained, even destroyed, by the fatalistic necessity of the mechanisms of the economic market. In the place of public deliberation, which is always connected to free choice (Aristotle, 2002; Locke, 1679 [1960]; Kant, 1797 [1977]; 
Rawls, 1971, 1993, 1999), by erasing the distinction between sovereign decision-making and natural spontaneity, neoliberal governments impose unrestricted obedience to the political (no longer the natural) spontaneous laissez-faire order. Since the whole of society ought to be organized in line with the created structure of the competitive economic market, public deliberation, along with its political solutions, is necessarily excluded from this neoliberal creation. What is excluded from decisionmaking on the neoliberal model is any notion of a public good that could be an object of desire on the part of a public, a people. Indeed, when individuals or groups attempt to pursue genuinely public goods (as opposed to self-interest, e.g., increasing public expenditure to safeguard public education), neoliberals communicate to citizens that there is no alternative to neoliberal assumptions. Publicity without a public, or the peculiar political function of TINA in that publicity, is central to this form of communication, as will become clear below. What it communicates is that individuals, groups and peoples ought to necessarily and inevitably choose those alternative(s) that are compatible with economic market conditions-from a basis of individual and private sovereignty, or from a concern for preserving, or even creating, (private) sovereignty.

"The Sovereign People" in classical and contemporary liberalism. Even if the invisible hand excludes the sovereign people, unlike neoliberalism, in liberalism the natural spontaneity of the economic market is compatible with the autonomy of politics. Rather than establishing a coincidence between the state and the market (i.e., a state created in analogy with the competitive market structure), and in spite of the endless tension between the economic order and the political order (e.g., the imposition of political limits on the liberty of natural economic markets), economic liberalism allowed for the combination of laissez-faire economics, i.e., the unrestricted maximization of the self-interest of homo economicus, with the people's sovereignty. Therefore, liberalism allows for the preservation of a space of public liberty, i.e., a space in which liberty not only depends on but also fosters the principles established by all members of a politically organized community who are potentially affected by the outcomes of decisions between two courses of action.

Smith's, (1776) economic liberal theory, for example, describes the economic market under the model of homo economicus and the metaphor of the invisible hand. Thus, even if this model implies a reinterpretation of state power (Foucault, 2008; Read, 2009), Smith neither translates the economic market into the political realm (unlike Buchanan and Tullock (1962), Hayek (1976) and Nozick (1974)) nor rejects the notion of the people and the metaphor of the political body. Smith operates with the concept of "different orders of people" (e.g., proprietors of land, cultivators and artificers, manufacturers and merchants (Smith, 1776 pp 380-381)) who have different access to education, seen as a public good. Contrary to neoliberal theory, which rejects the notion of a public good, i.e., a good that people pursue jointly, Smith not only stresses the existence of such goods (e.g., education, security, diversions, works) but also recognizes the role of the state as an autonomous, public (not private (e.g., Nozick, 1974)) institution that must provide such goods (Smith, 1776).

It is true that Smith ties sovereignty not to the people but to the monarch. Nonetheless, even if the difference between the sovereignty of peoples and monarchs is not a negligible issue, the monarch captures the possibility of reconciling the totality of points of view (e.g., interests, beliefs, ends), which transforms him or her into the ultimate legislator for the sake of every individual. Smith held that monarchs have a duty of "erecting and maintaining certain public works and certain public institutions, which it can never be for the interest of any individual, or small number of individuals to erect and maintain" (Smith, 1776, p 392). If it is true that monarchs are unable to perceive the totality from the perspective of the economic market (Smith, 1776; see Foucault, 2008), then the proper perspective for political deliberation cannot be that of the selfish individual. Indeed, the perspective of the economic market is not only irreconcilable with the monarch's total view but also simultaneously prevents him or her (and all individual economic agents) from appreciating and pursuing the public interest. Unlike Buchanan and Tullock, (1962), Smith accepts the existence of a public interest independent of individuals' particular interests; on his view, the political life depends on intentional and collective deliberation on the interests of all.

Moreover, since the monarch must be supported financially, in particular from the general contribution of the "whole society" (Smith, 1776, p 392), Smith does not consider the making of political policy from the perspective of the whole of society as a sign of totalitarianism, as Hayek, (1976) and Nozick, (1974) did. Consequently, Smith's economic liberalism not only clearly separates the spontaneity of the economic market from political deliberation but also neither positions the spontaneous order as the aim of politics nor transforms people into selfish individual sovereigns. Smith's homo economicus is thus able to behave simultaneously as a private individual in the economic market, maximizing his or her individual interest, and as a public person in public institutions, pursuing the well-being of all.

For this reason, from the perspective of liberalism, the metaphor of the invisible hand and homo economicus does not preclude the creation of a public personality who decides on public issues under a public common law. Smith's economic liberalism is aligned with the classic political liberalism of Locke, (1679 [1960], II, p 89) and Kant, (1795/96 [1977]).

Indeed, even if, rather than homo economicus, Locke's liberalism depends on the homo politicus and juridicus, and even if the conflict between rights and interests (Foucault, 2008) is acknowledged, Locke's and Kant's influence cannot be denied. Locke argues that when individuals come together to constitute political society, based on consent, this transforms them into a people, i.e., "one people, one body politic" (Locke, 1679 [1960], II, p 89). Underlying government constitutions, and ruled by the majority as a unified single body (1679 [1960], II, p 96), the sovereign people arises when, after consenting to the political constitution of their society, a group of persons comes together under a supreme government. In this political society, "every one of the members hath quitted [his or her] natural Power, resign'd it up into the hands of the community" (Locke, 1679 [1960], II, p 87). When they enter into society, individuals "make one people, one Body Politic, under one supreme Government" (Locke, 1679 [1960], II, p 89). With political society comes public political power, which is dependent on the public person or the people (see Locke's, (1679 [1960], II) systematic references to public will, public society, and society's one will).

Kant also clearly distinguishes between "the will of all individual men to live in accordance with principles of freedom within a lawful constitution [and the will of] all men together (i.e., the collective unity of the combined will)" (Kant, 1795/96 [1977], B 73-74, emphasis in the original). Thus, the Kantian perspective posits a public personality (e.g., the general will) through which persons share political principles not only as individuals but also as a common personality. People do not see themselves only as private individuals who may or may not share common ends under private right. They also view themselves as "the collective unity of the combined will", i.e., as a people or peculiar common personality, who share their common will as an end in itself (Kant, 1793 [1977]), 1795/6). The controversies surrounding 
Kant's social contract notwithstanding (Kersting, 1992; Riley, 1973), the social contract "oblige[s] every legislator to frame his laws in such a way that they could have been produced by the united will of a whole nation, and to regard each subject [...] as if he had consented within the general will" (Kant, 1793 [1977], A 250; emphasis added). Moreover, the agreed public political and legal principles ought to be established by all, i.e., by all who see themselves as sharing a common political identity, i.e., the "unity of the will of all the members" (Kant, 1793 [1977], A 245, emphasis in the original). Otherwise, instead of adopting a system of public right, i.e., a system of laws for a people or an aggregate of peoples (Kant, 1797 [1977]), political community would be structured around private right(s) (Kant, 1793 [1977]).

The fact that individuals deliberate as a common body does not strictly entail the privation of individual rights (e.g., liberty, property). In Locke's political philosophy, the constitution of the sovereign people is concomitant with the establishment of a coinstitutional charter, the main aim of which is to protect individuals' political rights (Locke, 1679 [1960]). In Kant's philosophy, to deliberate as a common body does not strictly entail leaving particular interests and perspectives behind (Kant, 1793 [1977]). Kant's political theory clearly rejects paternalistic and despotic political power, which imposes policies on individuals with regards to their pursuit of happiness (Kant, 1793 [1977], 1795/96 [1977]).

There is undoubtedly disagreement (e.g., between liberals (Locke, 1679 [1960]; Kant, 1793 [1997], 1795/96 [1997]), socialists (Badiou, 2016; Crick, 1987), and republicans (Habermas, 1989; Rousseau, 1762 [1964])) concerning how to reconcile the sovereign people, as a body politic, with individual liberty and particular interests. There are also, to be sure, differences within peoples (e.g., at the axes of class (Badiou, 2016), gender (Elstain, 1981), and race (Wilson, 2012)), along with disagreement concerning the adequacy of Locke's (and Kant's) theoretical political constructions of collective political personality, understood in analogy with the single body (e.g., the representatives' betrayal of the people's interest in the liberal social contract (Badiou, 2016)). On the contrary, neoliberalism replaces this conception of the intentional single body with the immediate, inevitable, and fatalistic order of the invisible hand.

Therefore, contrary to the liberal theoretical and practical tradition in its classical and contemporary forms, according to which the supreme power of the people is not indisputable or fatalistic but rather human and deliberative, the neoliberal supreme power is fatalistic. It thus does away both with the idea of the public realm (Hayek, 1976; Nozick, 1974), which pertains to a common good or shared interest (e.g., Hobbes's, (1651 [1996]) social contract), and with the idea of common personality, which pertains to a common identity as a common end (e.g., Locke's, (1679 [1960]), Rousseau's, (1762 [1964]), and Kant's, (1793 [1977], 1795/6) social contracts) and to the sovereignty of the people.

\section{TINA and the political role of publicity}

If individuals always ought to follow the immediate and unconditional orders of the invisible hand according to neoliberalism, then why do neoliberal politicians continue to feel the need to voice the claim that "there is no alternative" to neoliberal policies? In a perfect neoliberal society, it would not be necessary to publicize neoliberal premises. Individuals are irremissibly and intractably opposed when it comes to their well-being; they are committed neither to each other nor to political principles concerning the well-being of others (Brown, 2015; Dean, 2015; Foucault, 2008). Consequently, everybody maximizes his or her self-interest and in an almost solipsistic manner follows the orders of the invisible hand (see Buchanan's, (2000) political justification of economic market rules).

Nevertheless, neoliberal "political" society is not created ex nihilo. It depends on time and circumstances, namely the dismantling of the previous non-liberal order (e.g., demo liberalism in Europe (Harvey, 2005)). Because they are supported by individuals who follow different political ideologies and who see themselves as members of a political society, neoliberal politicians in liberal democracies must convince and persuade citizens that, instead of pursuing public well-being or the common good and following public rules, they should pursue their unrestricted private well-being instead. As a result, the institution of neoliberalism depends heavily on publicity, along with the maxim that "there is no alternative". Conversely, the implementation of neoliberal policies entails political secrecy with regards to the existence of the people as sovereign decision-makers.

Kantian publicity. Publicity has been viewed as a regulative ideal to solve particular social problems in particular historical contexts (Bohman, 1999) or as a set of constraints (or conditions) that limit public deliberation (Rawls, 1971). Controversy remains, however, concerning the meaning and scope of publicity (e.g., the differences between rational and empirical publicity (Davis, 1991) and hypothetical and actual publicity (Gosseries 2005)). There is also disagreement about the political and ethical value of publicity and secrecy (e.g., explicitly utilitarian defenses of secrecy (Bentham, 1843 [1999]; Sidgwick, 1893)) and their justification (e.g., political (Kant, 1793 [1977]) or ethical and psychological (Sidgwick, 1893)).

Despite these differences and controversies, Kant's political philosophy established an understanding of publicity as a criterion (or principle) for evaluating the justice of any political or legal policy (or maxim) (Bohman, 1999; Chambers, 2004; Davis, 1991; Laursen, 1986; Swabey, 1930). As a transcendental (rather than empirical) principle, valid axiomatically and without demonstration (Kant, 1795/96 [1977], B 99), the principle states that "[a]ll actions affecting the rights of the other human beings are wrong if their maxim is not compatible with their being made public". Accordingly, in analogy with the categorical imperative of morality, this first, negative formulation of the publicity principle, as a test of right and wrong (Kant, 1795/96 [1977]; see also Deligiorgi, 2002; Swabey, 1930) or justice and injustice (Davis, 1991), prescribes that every legal and political policy ought to be open to public scrutiny. Otherwise, not only does that policy remain inherently unfair and wrong (Kant, 1795/96 [1977], B 99), but it is likely to bring about undesirable consequences: the public confession of a maxim that cannot be expressed out loud and must remain entirely secret is likely to occasion opposition on the part of citizens in response to the injustice that threatens them (Kant, 1795/96 [1977], B 100).

Nevertheless, in Kantian political philosophy openness of this sort does not ensure the justice of a given maxim. Although openness may be a criterion of justice, this does not mean that all publicly proclaimed maxims are just, for "the person who has decisive supremacy has no need to conceal his maxims" (Kant, 1795/96 [1977], B 102). Even though the public confession of an unfair maxim would invite the resistance of all, decisive power can crush resistance. In the case of people's resistance to an unjust political power, "[t]he head of the state [...] is aware that he possesses the irresistible supreme power [...] [;] he does not have to worry that his own aims might be frustrated if his maxim became generally known" (Kant, 1795/96 [1977], B 103).

Since a despotic power does not need to hide its maxims (Kant, $1795 / 96$ [1977])—it can publicize its unfair rules without risking resistance-Kant proposes a second formulation of the 
transcendental principle of publicity. This states that "[a]ll maxims which require publicity if they are not to fail in their purpose can be reconciled both with right and with politics" (Kant, 1795/96 [1977], B 110). Roughly, Kant's concept of right refers to the restriction of each individual "freedom so that it harmonizes with the freedom of everyone else" (Kant, 1793 [1977], A 234; see also), and politics points to "an applied branch of right" (Kant, 1795/96 [1977], B 71). As an applied branch of right, political acts (e.g., legislation, the execution of policies) ought to ensure the freedom of every person. Politics always involves some element of obedience and command, but both ought to be grounded in freedom. Although political legislation is not without coercion (Kant, 1793 [1977], 1795/96 [1977]), B 71), any political maxim that commands behavior ought to be public and capable of being freely accepted by those who obey it.

Politics requires, then, agreement between those who command and those who obey, i.e., the validity and justice of public maxims ought ultimately to be related to the social contract (Deligiorgi, 2002). This means that when presented in public, politicians' maxims ought to comply with the agreed public political and legal principles "accepted by all concerned [and] willed by all individuals of a public" (Davis, 1991, p 410). Despite the differences between distinct publics (Davis, 1992) and lack of consensus on the actual or rational nature of the public underlying Kantian publicity (Davis, 1991, 1992), any maxims that do not conform to these public principles will be private, illegal, and unaccountable. Thus, in addition to referring to the openness and visibility (to all citizens) of political principles (which is opposed to secrecy), the Kantian approach to publicity also speaks to the Latin publicus and populus (which is opposed to the private). Moreover, the requirement of underlying political publicity aims to limit, and even to prevent, the unfair, abusive, and violent abuse of political power.

It is true that Kant's solution to unfair public policies that issue from despotic power is not completely satisfactory. He argues, for example, that the principle of publicity does not entail that citizens have a right to rebel against despotic power in response to the violation of agreed public principles (Kant, 1795/96 [1977], B, pp 101-103). On the one hand, the contract between the people and the sovereign does not include the use of violence against the latter, which would challenge his or her sovereign power (Kant, 1795/96 [1977], B 102); on the other hand, and as stated above, the supreme and absolute power "does not have to worry that his own aims might be frustrated if his maxim became generally known" and can "punish any rebellion by putting the ringleaders to death" (1795/96 [1977], B 102). With this said, the controversial nature of Kant's approach to the right of rebellion (Axinn, 1971; Chambers, 2004; Bennington, 2011; Laursen, 1986; Riley, 1973) does not negate the importance of the relationship between the openness of policies and political (and legal) agreement with regards to their content.

TINA and the publicity test. In contrast to the Kantian conception of the citizen, neoliberalism views TINA as both proclaimed by and addressed to private, self-interested individuals who, instead of seeking public well-being and following public rules, are right to follow their own unrestricted, private wellbeing. Under this maxim, individuals ought to "pursue their goals in such a way that they follow the inevitable law(s) of the spontaneous order". These private individuals agree on common principles that issue from a social contract that is established and followed in private- not one under which they are transformed into a sovereign people or a general will. Consequently, TINA is part of an unusual and peculiar concept of publicity-openness or visibility without a public (a populus or demos) - in which the public is reduced to a disparate set of individuals. It includes neither the notion of a populus, i.e., a unity of the wills of all members, nor its standing as ultimate lawmaker.

One may argue that under neoliberal premises appeal to the Kantian negative and positive hypothetical tests of publicity is absurd. There is neither an ideal public (e.g., the ideal public demanding justice (Davis, 1992)) nor an actual public (e.g., literate, university scholars (Davis, 1992)) to whom neoliberal politicians might prescribe the maxim of "pursuing their goals in such a way that they follow the inevitable law(s) of the spontaneous order". As noted above, in a perfect neoliberal society it would not be necessary to make neoliberal premises public because there is no such political person, the sovereign people, to whom those premises might be addressed. Indeed, the inexistence of the people seems to run against the idea of questioning political maxims' compliance with a hypothetical (or actual) conception of publicity.

Nevertheless, since there is no such thing as a perfect neoliberal society, the invocation of the Kantian hypothetical test of publicity is not absurd. Despite its ideological commitments, the neoliberal order must somehow deal with the fact that an actual public, the people (the populus), really does exist, and that citizens in liberal democracies still value this self-conception. In order to implement its own ideal, i.e., to create a spontaneous society, the neoliberal order must therefore bring it about that citizens cease to view themselves as co-deliberators on public issues under a common political identity (the unity of the will of all members) and that they ultimately give up the political responsibility of being lawmakers.

Indeed, TINA plays an important role in this process. As a response to the "residual" existence of the people, TINA is a means of disempowering citizens and preventing political resistance to the extent that it publicizes peoples' lack of power, reinforcing that self-image while bolstering the despotic power of the neoliberal order. The fact that neoliberals loudly and visibly profess that "there is no alternative" reveals not only their lack of fear concerning the possible frustration of their policies as a result of their being made public, but also, and mainly, their political intention to crush peoples' political choices. The repeated articulation of TINA works to bring about political resignation, if not capitulation, ultimately weakening resistance (which becomes an absurd notion).

Consider, for example, recent events in Greece. In the belief that alternative policies (e.g., to stimulate consumption and demand in order to prevent a negative spiral of declining confidence) would help to tackle the European debt crisis, Greek citizens elected the extreme left-wing party Syriza in 2015. Syriza, however, now governs under a neoliberal program (much like those advocated by the liberal conservative New Democracy party and the social democratic PASOK). The fact that three different parties with distinct political ideologies have governed under the same political program reveals the extent to which neoliberal international and global political institutions (e.g., the International Monetary Fund (IMF)) have imposed their values on citizens, who are no longer given a genuine choice. The undermining of citizens' self-image as co-legislators and the perpetuation of the neoliberal order are therefore intimately connected: the public and visible articulation of TINA serves to denigrate the self-conception of the people as an intentional, collective body, thereby ensuring the acquisition and preservation of neoliberal political power.

TINA therefore constitutes a threat to the very idea of the public, and to politics as such; as a persuasive rhetorical strategy, it invites citizens to consent to the inevitability of the mandates of the spontaneous order and, ultimately, to surrender their political power. The historical development of the neoliberal order has 
meant that neoliberal societies still rely on key demo-liberal institutions (e.g., elections), and thus that individual choice is made under majority rule. Unlike the neoliberal understanding of majoritarian rule-which is framed by the model of straightforward individual wealth maximization (Buchanan and Tullock, 1962; Brennan and Buchanan, 1985) - this form of rule is still generally conceived by citizens, given deep-seated understandings of democracy and legitimacy, in terms of deliberation (and rule) by the people (Locke, 1679 [1960]; Kant, 1793 [1977]; Rawls, 1971, 1993). TINA constitutes a threat to this notion, and indeed to any notion of the power of the collective to set political ends and realize political values. Its repeated articulation undermines the very existence of the sovereign people, making the populus complicit in its own dissolution.

TINA, "Nobody", and secrecy. Although it is implied by TINA, neoliberals do not publicly and visibly profess that "there is no such thing as the people". As suggested above, neoliberal thinkers do not explicitly argue against the meaningfulness of the people, as they do against society and states (Brennan and Buchanan, 1985; Hayek, 1976; Nozick, 1974). Since neoliberals still function within democratic electoral institutions, which often involve the rhetoric of the well-being of the people, when asking citizens to choose neoliberal policies politicians cannot publically proclaim, like Odysseus to the cyclops Polyphemus, that their policies address "nobody". If their status as "nobodies" were to be made public under neoliberal rule, the people would be far less eager to elect neoliberal politicians, which would entail the failure of neoliberal intentions. As a result, neoliberal politicians keep secret neoliberalism's rejection of the idea of the people while publically proclaiming that they address "everybody".

Neoliberal politicians therefore adhere to the following maxim: "pursue neoliberal goals by letting people think (wrongly) that other legitimate goals are being pursued". This maxim stems from the fact that their goal- "overcoming" public deliberation-will be more easily attained if it is kept secret. In particular, the imposition of leadership by the invisible hand (neoliberalism's true goal) is hidden by the supposition that neoliberal politicians are acting in the best interest of the people (the goal they present to the people). On the basis of this supposition, neoliberals profess that there is no alternative to their political policies while agreeing privately and secretly on public issues in a way that bypasses the people altogether, only later to proclaim that these policies were inevitable. A key example of this is the Transatlantic Trade and Investment Partnership (TTIP), a bi-lateral trade agreement between the EU and the US that was created mostly in secret. The trade negotiations were about reducing the regulatory barriers to trade for big business, such as food safety laws, environmental legislation, banking regulations, and the sovereign powers of individual nations. The TTIP encountered strong resistance from European and American citizens, which forced neoliberal officials to put it provisionally on hold (www.guengl. eu/.../after-last-minute-withdrawal-of-ttip-vote-gue-ngl-calls-

for-genuine-public, Accessed $29 \mathrm{Dec}$ ). For instance, if Greenpeace had not disclosed the terms of the agreement, this would have certainly remained entirely secret, and later presented as inevitable.

Denial of the sovereign people is concomitant with the overlapping of (or better, confusion between) state secrecy and individual privacy. Secrecy involves the intentional concealment of information from those who may have a right to it (Pozen, 2010). This intentional concealment depends on private, selfinterested individuals who, instead of seeking public well-being and following public rules, are told they are right to follow their own unrestricted, private well-being. By contrast, privacy involves a person's exclusive or restricted access to a realm of his or her own, and thus protection from unwanted access by others (Bok, 1982; Gavison, 1980; Moor, 1990; see also Clarke, 1999; DeCew, 1997; Fried, 1990; Parent, 1983; Warren and Brandeis, 1890). What the contemporary situation shows is that neoliberals treat public secrecy as if it were a matter of individual privacy. Instead of accepting that citizens have rights to the information being concealed from them, neoliberals suppose that they have a right to exclusive access to "political" information. Treating the "political realm" as a kind of private property, neoliberal officials protect themselves from unwanted access by citizens, from whom they should derive their authority and to whom they should be accountable.

It is true that respect for accountability to the people does not necessarily entail complete transparency or the total forbearance of secrecy on the part of the state. Far from being irreducibly opposed, secrecy and publicity are mixed (Bentham, 1843 (1999); Elster, 1998), symbiotic (Birchall, 2011), and complementary (Horn, 2011). Moreover, political secrecy is not always illegitimate. For example, as a "regrettable necessity" (Horn, 2011, p 117), secrecy often serves as a means of ensuring the public or national interest (e.g., preventing enemies from accessing information that can harm national interests), of enhancing public deliberation and decision-making (Thompson, 1999), of protecting citizens' privacy, and of combatting coercion (Chinen, 2009; Gutman and Thompson, 1996; Losoncz, 2016; Pozen, 2010).

Indeed, despite the abstract and formal nature of Kant's approach to publicity, his political philosophy does not necessarily reject political secrecy (Gosseries, 2005). There is an irreducible element of secrecy that publicity can never dispel (Bennington, 2011; Davis, 1991). It is true that there is an unclear relationship between self-frustration and injustice in Kant's political concept of publicity (Gosseries, 2005). It is also true that the Kantian examples are sometimes obscure (Elster, 1998). However, just as under a despotic power an unjust public maxim need not be self-frustrating, so under a fair and accountable power, based on the will of the people, secrecy need not be unjust and impermissible (e.g., covert police interventions, or the classification of military documents).

In addition, the ethical and political nature of publicity entails the possibility of a transparent veil of secrecy (Kant, 1798 [1977]), or open secrecy (Bennington, 2011), which occurs when citizens and politicians consent to illegal or unconstitutional policies while publicly behaving as if they do not. Citizens (and politicians) often agree to illegal and unconstitutional policies because they are taken to further their interests (i.e., promises of job creation, lower taxes, greater "freedom"). Indeed, open secrecy of this sort often presupposes acknowledgement of-and, even more perversely, respect for-the foundational legislative power of the people. Politicians know that they need the support of the people if they are to acquire and preserve their power. In exchange for support for policies that violate constitutional standards, they offer untold material benefits-incentives for citizens to shut their eyes and ears to the destruction of their democratic institutions.

If there is always an irreducible element of secrecy that the requirement of political publicity can never dispel, what is really at stake when it comes to neoliberalism's secrecy about its attitude toward "the people" is not the fact of secrecy itself. What seems especially controversial, even disturbing, is the fact that neoliberal secrecy has no basis in the consent of the people. Indeed, contrary to secrecy at the level of certain forms of police or military intervention, neoliberalism's secret commitment to the nonexistence of the sovereign people would seem to be wholly illegitimate-it is neither an acceptable form of protective secrecy 
nor an acceptable form of open secrecy. Neoliberals justify their secrecy by citing the supposed fact that the policies they advocate are in the people's best interests. They do so while denying the existence of the people and pushing policies that would destroy the possibility of collective deliberation.

Even if the people's support of neoliberalism can be seen as an oxymoron, however, political choice (e.g., elections) under the maxim of "pursuing neoliberal goals by letting people think (wrongly) that other legitimate goals are being pursued" can contribute to the neoliberal political project of dismantling the foundational political power of the people. In truth, even if the violent imposition of neoliberal policies by powerful social forces is acknowledged (Hall, 2011; Klein, 2007; Overbeek, 1993; Teubal, 2004), when people subscribe to neoliberal programs in exchange for the illusory promise of personal and collective well-being they consent to political policies that necessitate the surrender of their political power.

Although neoliberals could publicize their belief that there is no such thing as the sovereign people without putting their aims at risk, as indeed already happens when they articulate TINA, they have yet to profess this explicitly. One may suppose, however, that even if neoliberals were to publicize their disdain for the sovereign people, this would not necessarily frustrate their aims and intentions. The disclosure of their commitment to the non-existence of that people might well be passively accepted by a powerless citizenry, revealing the extent to which neoliberal power has become unlimited and despotic and providing support for the thought that "the stronger a despotic power the larger the spectrum of maxims that may pass the publicity test" (Gosseries, 2005, p 6; see also Arendt, 1951). Under unbridled power, there is no limit to the threatening statements (and acts) that can be levelled against "enslaved" peoples. In situations where political power has yet to become fully unbridled, the extent to which leaders must resort to deception and manipulation reveals the important limits to despotism imposed by the existence of the people and the imperative to publicity. Although it has been perverted under neoliberalism, publicity remains an important public criterion of fairness and legitimacy.

\section{Conclusion}

This paper has shown that TINA is communicated against the backdrop of a peculiar concept of publicity. As an openly professed principle, this is the concept of openness and visibility without a public (a populus or demos). The paper has also shown that the main content of publicity without a public is the unconditional neoliberal maxim of TINA itself.

The above argument compares the neoliberal approach to publicity with Kantian political philosophy, showing that the Kantian approach to publicity refers to public agreement on political rules. Moreover, it shows that in addition to referring to the openness and visibility to all citizens of political principles (opposed to secrecy), the Kantian approach to publicity also speaks to the Latin publicus (Cicero, 1999, I, p 39). Despite the controversies associated with Kant's view (e.g., his approach to the right to rebellion (Axinn, 1971; Chambers, 2004; Bennington, 2011; Laursen, 1986; Riley, 1973)), the requirement of publicity articulated in his principle aims to limit, and even to prevent, unfair, abusive, and violent public policies. On the basis of this comparison, this paper has argued that publicity without a public is the expression of visibly despotic and arbitrary power. Although it is pursued under the banner of liberty, publicity without a public reveals the neoliberal project of absolute supremacy, openly and explicitly undermining liberty and public choice. Finally, this paper has argued that since state secrecy and individual privacy overlap under neoliberalism, neoliberal publicity does not dispense with secrecy.

Possible areas of future research include inquiry into why contemporary liberal theories tend to avoid the political category of "the (sovereign) people", the political importance of which is undeniable in Locke's, (1679 [1960]), and Kant's, (1793 [1977], 1795/6 [1977]) liberal theories. The continued trend of relating the political category of "the people" to socialism, following Nozick, (1974), not only risks reducing liberalism to neoliberalism but also undermines a potentially useful concept in the battle against the theoretical and practical rejection of the idea of collective, intentional decision-making (e.g., the battle against populism and the erosion of democratic institutions (Brown, 2006, 2015; Bruff, 2014; Kreuder-Sonnen and Zangl, 2015; Orphanides, 2014; Schmidt and Thatcher, 2014)). The conflation of liberalism and socialism (Nozick, 1974), or liberalism and neoliberalism, is certainly bad enough. Even worse, however, this conflation may cause some to think that liberal political theory, in the form of neoliberalism, also rejects the existence of political society. What is risked is a situation where illiberal and undemocratic political alternatives position themselves to fill the vacuum left by a system that, at its ideological core, cannot acknowledge the people's claims or well-being.

As this paper has shown, because of its appropriation of liberal democracy, neoliberalism makes use of traditional democratic rhetoric (e.g., "the well-being of the people(s)") and certain demoliberal institutions (e.g., elections). Nevertheless, future research could add to the already existing literature on democracy and neoliberalism (Leys, 2003; Springer, 2011; Swyngedouw, 2015) consideration of the extent to which democracy in general, and representative democracy in particular, remains an oxymoron under neoliberalism. In addition to rejecting the main basis of democracy, the sovereign people, neoliberalism threatens political representation as such. Finally, since TINA is a discourse, it would be worthwhile to identify how neoliberalism is produced discursively.

Received: 18 July 2017 Accepted: 24 October 2017

Published online: 21 November 2017

\section{References}

Agamben G (1996) Mezzii Senza Fine: Note sulla politica. Bolatti Boringhieri, Turim

Antonakakis N, Collins A (2014) The impact of fiscal austerity on suicide: on the empirics of a modern Greek tragedy. Soc Sci Med 39-50

Arendt H (1951) The origins of totalitarianism. Harcourt, Brace \& Co, New York, NY

Aristotle (2002) The Politics (trans. Carnes Lord). University of Chicago Press, Chicago

Axinn S (1971) Kant, authority, and the French revolution. J Hist Ideas 32:423-432 Badiou A (2016) Twenty Four Notes on the Uses of the Word "People". In: Allen, A (ed) What is a People. (New directions in Critical Theory). Columbia University Press, New York, NY, p 21-31

Ball L, Furceri D, Leigh D, Loungani P (2013) The distributional effects of the fiscal austerity. DESA working paper $\mathrm{N}^{\circ}$. United Nations, New York, NY, p 129

Barker R (1987) Socialism. In: Miller D, Coleman J, Connolly W, Ryan A (eds) The Blackwell encyclopedia of political thought 1987. Blackwell, Oxford, Cambridge, Massachusetts, pp 485-489

Barney D (2008) Politics and emerging media. the revenge of publicity. Glob Media J 1:89-106

Barro R (2009) Government spending is no free lunch: how Democrats are peddling voodoo economics. Wall Street J, 22 January. http://www.wsj.com/ articles/SB123258618204604599. Accessed 29 Nov 2015

Bennington G (2011) Kant's open secret. Theory Cult Soc 28:26-40

Bentham J (1843) [1999]) Political tactics. In: James M, Blamires C, Pease-Watkin C (eds) The collected works of Jeremy Bentham. Clarendon Press, Oxford, $p$ 1999 
Birchall C (2011) Introduction to "Secrecy and Transparency": the politics and opacity and openness. Theory Cult Soc 28:7-25

Bok S (1982) Secrets: on the ethics of concealment and revelation. Pantheon, New York, NY

Bohman J (1999) Citizenship and norms of publicity: wide public reason in cosmopolitan societies. Polit Theory 27(82):176-202

Breaugh M (2007) L' éxpérience Plébéienne: Une Histoire Discontinue de la Liberé Politique. Payot, Paris

Brennen G, Buchanan (1985) The Reason of Rules: Constitutional Political Economy. Liberty Fund. Indianapolis

Brown W (2006) American nightmare: neoliberalism, neoconservatism, and democratization. Polit Theory 34:704

Brown W (2015) Undoing the demos: neoliberalism's stealth revolution. Zone Books, Cambridge, MA

Bruff I (2014) The rise of authoritarian neoliberalism. Rethink Marx 26(1):113-129

Buchanan J, Tullock G (1962) The calculus of consent: the logical foundations of constitutional democracy. Liberty Fund, Indianapolis

Buchanan J (1990) The domain of constitutional economics. Const Polit Econ 1 (1):1-18

Buchanan J (2000) The soul of classical liberalism. Indep Rev 5:111-119

Chambers S (2004) Behind closed doors: publicity, secrecy and the quality of deliberation. J Polit Philos 12:389-410

Chinen M (2009) Secrecy and democratic decisions. Quinnipiac Law Rev 27:1-53

Cicero (1999) On the commonwealth and on the laws. Cambridge University Press, Cambridge, New York, NY, Melbourne, Madrid, Cape Town, Singapore, São Paulo

Clarke R (1999) Secrets: the ethics of concealment and revelation. Vintage Books, New York, NY

Cochrane J (2009) Fiscal stimulus, fiscal inflation or fiscal fallacies. http://faculty. chicagobooth.edu/john.cochrane/research/papers/fiscal2.htm. Accessed Nov 2015

Crick B (1987) Socialism. McGraw-Hill Education, New York, NY

Dahl R (1998) On democracy. with a new preface and two new chapters by Ian Shapiro. Yale University Press, New Haven \& London

Davis K (1991) Kantian "Publicity" and political justice. Hist Philos Q 8(4):409-421

Davis K (1992) Kant's different "Publics" and the justice of publicity. Kant-Stud 83 (2):170-184

Dean J (2003) Why the net is not a public sphere. Constellations 10:95-112

Dean J (2008) Communicative capitalism: circulation and foreclosure of politics. In: Boler M (ed) Digital media and democracy: tactics in hard times 2008. The MIT Press, Cambridge, Massachusetts. London, England, pp 101-121

Dean J (2015) Neoliberalism's Defeat of Democracy. Critical Inquiry. http:// criticalinquiry.uchicago.edu/neoliberalisms_defeat_of_democracy).

DeCew J (1997) In pursuit of privacy: law, ethics, and the rise of technology. Cornell University Press, Ithaca, NY

Deligiorgi K (2002) Universality, publicity, and communication: Kant's conception of reason. Eur J Philos 10:143-159

Edmiston D (2014) The age of Austerity: contesting the ethical basis and financial sustainability of welfare reform in Europe. J Contemp Eur Stud 22(2):11-131

Elstain JB (1981) The public man, private woman: woman in social and political thought. Princeton University Press, Princeton, NJ

Europe (2015) http://www.ft.com/cms/s/0/469e55f2-1bf3-11e5-8201cbdb03d71480. 710html\#axzz3pbTFPzLn

Elster J (1998) Deliberative and Constitution making. In: Elster J (ed) Deliberative democracy. Cambridge University Press, Cambridge, pp 97-122

Foucault M (2008) The birth of biopolitics. Palgrave Macmillan, New York, NY

Fraser N (1999) Rethinking the public sphere: a contribution to the critique of actually existing democracy. Soc Text 25/26:56-80

Fried C (1990) Privacy: a rational context. In: Ermann MD, Williams MB, Guitierrez C (eds) Computers, ethics, and society 1990. Oxford University Press, New York, NY, pp 50-63

Friedman M (1953) Essays in positive economics. University of Chicago Press, Chicago

Gavison R (1980) Privacy and the limits of the law. Yale Law J 89:421-421

Gosseries A (2005) Publicity. In: Zalta E (ed) The Stanford Encyclopedia of Philosophy. Stanford University, Stanford. https://plato.stanford.edu/entries/ publicity/ Acceded 3 Jan 2017

Greer S (2014) Structural adjustment comes to Europe: lesson for Eurozone from the conditionality debates. Glob Social Policy 14(1):51-71

Gutman A, Thompson D (1996) Democracy and disagreement. The Belknap Press of Harvard University Press, Cambridge, Massachusetts

Habermas J (1989) The structural transformation of the public sphere: an inquiry into a category of Bourgeois Society. The M.I.T. Press, Cambridge, MA

Habermas J (2000) Crossing globalization's valley of tears. New Perspect Q 17 (4):51-7

Hall S (2011) The neoliberal revolution. J Cult Stud 25(6):705-728

Harvey D (2005) A brief history of neoliberalism. Oxford University Press, Oxford, New York, NY
Hayek F (1976) Law, legislation and liberty. the mirage of social justice, Vol. II. The University of Chicago Press, Chicago and London

Hobbes T (1996) Leviathan. Oxford University Press, Oxford, 1651

Horn E (2011) Logics of Political Secrecy. Theory Cult Soc 28:103-122

Jenkins S (2007) Thatcher's Legacy. Political Stud Rev 5:161-171

Kant I (1977) Über den Gemeinspruch: Das mag in der Theorie richtig sein, taugt aber nicht für die Praxis. In: Weischedel W (ed) Werke in Zwölf Bänden Band XI 1977. Suhrkamp Verlag, Frankfurt am Main, 1793, pp 125-172

Kant I (1977) Zum ewigen Frieden. Ein philosophischer Entwurf. In: Weischedel W (ed) Werke in zwölf Bänden Band XI 1997. Suhrkamp Verlag, Frankfurt am Main, 1795/96, pp 195-251

Kant I (1977) Die Metaphysik der Sitten. In: Weischedel W (ed) Werke in zwölf Bänden. Band VIII 1997. Suhrkamp Verlag, Frankfurt am Main, 1797

Kant I (1977) Der Streit der Facultäten. In: Weischedel W (ed) Werke in zwölf Bänden Band XI 1997. Suhrkamp Verlag, Frankfurt am Main, 1798, pp 265-393

Kersting W (1992) Politics, freedom, and order: Kant's political philosophy. In: Guyer P (ed) The Cambridge Companion to Kant 1992. Cambridge University Press, New York, NY, pp 341-368

Klein N (2007) The Shock Doctrine: the rise of disaster capitalism. Allen Lane, London

Kreuder-Sonnen C, Zangl B (2015) Which post-Westphalia? International organizations between constitutionalism and authoritarianism. Eur J Int Relat 31 (3):568-594

Larner W (2006) Neoliberalism: policy, ideology, governmentality. In: Goda M (ed) International political economy and poststructural politics. Palgrave Macmillan, New York, NY, pp 199-218

Laursen J (1986) The Subversive Kant: the vocabulary of "public" and "publicity". Political Theory 14:584-603

Leys C (2003) Market-driven politics: neoliberal democracy and public interest. Verso, London, New York, NY

Locke J (1679) Two treatises of government. In: Laslett P (ed) Cambridge texts in the history of political thought. Cambridge University Press, Glasgow, p 1960.

Losoncz M (2016) Engagement against/for secrecy. Filos I Drustvo 27(29):428

Moor J (1990) The ethics of privacy protection. Libr Trends 39:69-82

Mudge S (2008) The state of the art. what is neoliberalism? Socio-Econ Rev 6:703-731

Munck R (2003) Neoliberalism, necessitarism and alternatives in Latin America. There is no alternative (tina). Third World Q 24:495-511

Mni Deustche Börse Group (2012) https://www.marketnews.com/content/merkelpassos-coelhopraise-portuguese-reform-efforts

Novelli J (2002) Instituições Políticas e Idéias Econômicas: o caso do Banco Central do Brasil (1965-1998). Annablume, São Paulo

Nozick R (1974) Anarchy, state, and Utopia. Blackwell, Oxford

Orphanides A (2014) The Euro Area crisis: politics over economics. Atl Econ J 42:243-263

Overbeek H (ed) (1993) Restructuring hegemony in the global political economy. the rise of transnational nep-liberalism in the1980s. Routledge, London and New York, NY

Overbeek H, Pijl Kessvander (1993) Restructuring Capital and Restructuring Hegemony: Neoliberalism and the Unmaking of the Post-War Order. In Overbeek H (ed) Restructuring hegemony in the global political economy. The rise of transnational nep-liberalism in the 1980s 1993. Routledge, London and New York, NY, pp 1-27

Parent WA (1983) Privacy, morality and the law. Philos Public Aff 12:269-288

Pozen D (2010) Deep secrecy. Stanf Law Rev 65:257-340

Queiroz R (2016) Neo-liberal TINA: an ideological and political subversion of liberalism. Crit Policy Stud 10(4):1-20

Ramey J (2015) Neoliberalism as a political theology of chance: the politics of divination. Palgrave Communications 1: 1-9

Rawls J (1971) A theory of justice. Oxford University Press, Oxford

Rawls J (1993) Political liberalism. Columbia University Press, New York, NY

Rawls J (1999) The law of peoples, with "The Idea of Public Reason Revisited". Harvard University Press, Cambridge, Massachusetts, London, England

Read J (2009) A genealogy of homo-economicus: neoliberalism and the production of subjectivity. Foucault Stud 6:35-36. ISSN: 1832-5203

Reuters (2015) http://www.reuters.com/article/2015/07/16/us-eurozone-greeceidUSKBN 0P40EO20150716

Riley P (1973) On Kant as the most adequate of the social contract theorists. Polit Theory 1(4):450-471

Rousseau JJ (1964) Du Contrat social. Gallimard, Paris, 1762

Schmidt V, Thatcher M (2014) Why are neoliberal ideas so resilient in Europe's political economy? Crit Policy Stud 8:340-347

Sidgwick H (1893) The methods of ethics. MacMillan and Co, London

Sieyes EJ (1989) Qu'est ce que le Tiers État, Precedé de L’Essai sur les Privilèges. PUF, Paris, 1789

Smith A (1776) An inquiry into the nature and causes of the wealth of nations, vol 2, W. Strahan and T. Cadell, London 
Springer S (2011) Public space as Emancipation: meditations on anarchism, radical democracy, neoliberalism and violence. Antipode 43(2): 525-562

Stiglitz J (2013) The price of inequality. Penguin Books, London

Swabey MC (1930) Publicity and measurement. Int J Ethics 41:96-114

Swyngedouw E (2015) Interrogating post-democratization: reclaiming egalitatian political spaces. sustained unsustainability: barriers to transformative actionUniversity of Bath.

Teubal M (2004) Rise and collapse of neoliberalism in Argentina: the role of economic groups. J Dev Soc 20(3-4):173-188

Thompson D (1999) Democratic secrecy. Political Sci Q 114:181-193

Ugarteche O (1998) La Arqueología de la Modernidad: El Perú Entre la Globalización y la Exclusión. Centro de Estudios y Promoción del Desarrollo. Desco, Lima

Vellinga M (1997) El Cambio del papel del Estado en America Latina. Siglo Veintiuno Editores, México

Warren S, Brandeis L (1890) The right to privacy. Harv Law Rev 14:v193-220

Wilson K (2012) Race, racism, and development: interrogating history, discourse and practice. Zed Books, London, New York, NY

\section{Data availability}

Data sharing is not applicable to this article because no quantitative datasets were generated or analyzed to produce the current study.

\section{Additional information}

Competing interests: The author declares no competing financial interests.

Reprints and permission information is available online at http://www.nature.com/ reprints

Publisher's note: Springer Nature remains neutral with regard to jurisdictional claims in published maps and institutional affiliations.

(c) (i)

Open Access This article is licensed under a Creative Commons Attribution 4.0 International License, which permits use, sharing, adaptation, distribution and reproduction in any medium or format, as long as you give appropriate credit to the original author(s) and the source, provide a link to the Creative Commons license, and indicate if changes were made. The images or other third party material in this article are included in the article's Creative Commons license, unless indicated otherwise in a credit line to the material. If material is not included in the article's Creative Commons license and your intended use is not permitted by statutory regulation or exceeds the permitted use, you will need to obtain permission directly from the copyright holder. To view a copy of this license, visit http://creativecommons.org/ licenses/by/4.0/.

(C) The Author(s) 2017 